\title{
Human Scalp Hair as Fiber Reinforcement in Cement Concrete
}

\author{
Shanker Lal Meghwar ${ }^{1 a}$, Ghous Bux Khaskheli², Aneel Kumar ${ }^{1 b}$ \\ RECEIVED ON 13.04.2018, ACCEPTED ON 03.05.2019
}

\begin{abstract}
The construction industry is the largest manufacturing industry, which produces concrete and other related materials for construction of infrastructure around the world, after the food production industry. This industry requires a lot of natural resources like aggregates, limestone etc. to produce finished product such as concrete and cement. These natural resources are limited and have to deplete one day, so alternate to these resources are required. On the other hand, this industry produces a large amount of waste material that creates environmental pollution. Thus, recycling the waste as potential raw material and to produce a usable product is the need of present era for sustainable construction. This study presents the quantitative analysis of HSH (Human Scalp Hair) as fibers in cement concrete. This study aims to investigate the behaviour of concrete in terms of their mechanical properties when $\mathrm{HSH}$ are used as fibers. A detailed investigation on two types of concrete specimens i.e. cylindrical $(150 \mathrm{~mm}$ diameter and $300 \mathrm{~mm}$ height $)$ and prism $(150 \mathrm{~mm}$ depth, width and $600 \mathrm{~mm}$ length) made with a different proportion of HSH as fibers and concrete mix ratios, was carried out. In this study, various proportions of $\mathrm{HSH}$ added in concrete that includes $0 \%, 1 \%, 2 \%$ and $3 \%$ by weight of OPC (Ordinary Portland Cement). All specimens were cast at two concrete mix ratios i.e. 1:2:4 and 1:1.5:3 with 0.50 W/C (Water-Cement Ratio). Moreover, specimens were tested in UTM (Universal Testing Machine) at 28 days curing age, for splitting tensile strength and flexural strength of concrete. It was observed from the experimental analysis that there is an improvement in mechanical properties of concrete at specific percentage of HSH and reduction of workability and density with increasing percentages of $\mathrm{HSH}$.
\end{abstract}

Key Words: Fiber Reinforced Concrete, Human Scalp Hair, Municipal Solid Waste, Recycling of Waste, Environmental Friendly, Mechanical Properties of Concrete.

\section{INTRODUCTION}

$\mathrm{T}$ To cope with present needs and requirements without risking the needs of future generations to come is the ultimate aim of present sustainable development. Sustainable development is an economic activity that is in harmony with the earth's eco-system. This is the reason, many researchers are working on recycling of waste stuff rather consuming limited natural resources and producing useful products in various industries.
Presently, sufficient increase in human population produces a huge amount of human scalp hair (HSH) waste. The HSH are being thrown in open dumps and considered as municipal solid waste (MSW), useless or waste material in most of the societies. Thus, it is found in municipal waste streams in almost all urban cities and towns throughout the world [1-2]. In developing countries, these HSH either burnt openly with MSW or thrown in sewerage lines through washrooms. In both cases, they produce an adverse effect on the environment. When human hair thrown

\footnotetext{
${ }^{1}$ Department of Civil Engineering, Mehran University of Engineering and Technology, Jamshoro, Pakistan.

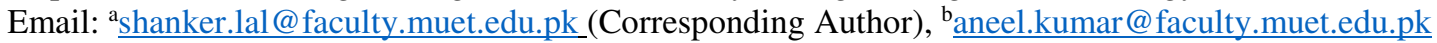

${ }^{2}$ Department of Civil Engineering, Isra University, Hyderabad, Pakistan. Email: gbk60@hotmail.com

This is an open access article published by Mehran University of Engineering and Technology, Jamshoro under CC BY 4.0 International License. 
in domestic sewerage lines, they block the sewer and increase the nitrogen concentration in sewage water and ultimately sewer water overflows into the streets through manholes. When HSH burn openly, it causes several respiratory problems. Open dumps of hair produce hair dust which causes discomfort among the locality that dwells beside. In low population areas, hairs are thrown away in nature where they take several years for decomposition. The burning of $\mathrm{HSH}$ produces a foul odour and harmful gases such as ammonia, carbonyl sulphide, hydrogen sulphide, sulphur dioxide, phenols, nitrites, pyrroles and pyridines [1,3], which leads the environment towards its degradation.

The rate or speed of scalp hair growth is about $12.7 \mathrm{~mm}$ per month or about $152.4 \mathrm{~mm}$ per year; weighing approximately 80-100gm per annum [1]. Considering the total population of the world i.e. 7 billion [4], which produces approximately $6 \times 10^{5}$ tons of scalp hair annually. On the other hand, a similar amount of hair are being dumped in the MSW from previous number of years. Considering this aspect, there has been a growing emphasis on the utilization of waste materials and by-products in construction activities. Use of waste materials not only helps in getting them utilized but also has numerous indirect benefits such as saving in energy and protection of the environment.

Improving the brittle behaviour of concrete fibers like steel, synthetic, plastic etc. are added in plain concrete. Reinforcing a brittle composite with discrete fibers is an old age concept but now a day's use of fiber in concrete for improving the ductility and flexural strength started in the early1900s [5-6]. The fibers in cement concrete increase the tensile and flexural strength [7-15]. It delays the growth of cracks and increases the toughness [3]. Fibers control the cracking due to plastic and drying shrinkage [15-18]. Fibers increase the shear and punching resistance of concrete [19-21]. The micro fibers delay the growth of small cracks, while macro fibers improve the postcracking behaviour of concrete [14, 22-23].

HSH's strand has high tensile strength and friction coefficient. Due to this reason, human hair has been used for reinforcing clay based construction in rural areas of India, Bangladesh, Syria [1, 24] and in
European countries [25] with clay and other binders in plastering the house walls. Using human hair as fiber can reduce the shrinkage of more than $90 \%$ [26]. It improves the tensile resistance and enhances the compressive strength of concrete by more than three times [27]. Jain D. and Kothari A. [26] has found experimentally that adding $1.5 \%$ human hair by volume in plain concrete had raised the flexural strength up to $8.6 \%$ and $22 \%$ in compressive strength of concrete. Similarly, Meghwar e. al. [29] concluded that $1 \%$ addition of $\mathrm{HSH}$ by weight of cement could increase $26.8 \%$ compressive strength at 1:2:4 mix ratio with $0.50 \mathrm{~W} / \mathrm{C}$ ratio. Batebi et al. [30] argued that hair having a length of $15 \mathrm{~mm}$ and $60 \mathrm{~mm}$ reduced the shrinkage in hair reinforced concrete when used in $0.4 \%, 0.8 \%$ and $1.2 \%$ by weight of mortar.

Physical properties of fiber like diameter, length etc. has a direct relation on various properties of concrete [28]. The smaller the fiber diameter i.e. higher the aspect ratio (length to diameter ratio), then fiber dispersion in concrete is difficult. On the other hand, smaller the fiber length i.e. lowers the aspect ratio, easier the fiber dispersion in fresh concrete [31]. Best advantages can be achieved when fiber orientation is unidirectional and parallel to the applied load and less benefit when randomly oriented in three dimensions. So far, it is very difficult to arrange and disperse the fibers in one direction for getting the maximum benefit because of the shorter length of fibers [32-35]

\section{EXPERIMENTAL INVESTIGATION}

\subsection{Research Methodology}

Research methodology adopted to ascertain the behaviour of HSH as fiber reinforcement in cement concrete. Thus, for experimental analysis of $\mathrm{HSH}$ in cement concrete is investigated in terms of four physical properties of concrete i.e. workability of fresh concrete, splitting tensile strength, flexural strength and density of concrete. The mould for slump test was a frustum cone (100, 200 and 300mm top diameter, bottom diameter and height of cone respectively); for splitting tensile strength, cylinder $(150 \mathrm{~mm}$ diameter and $300 \mathrm{~mm}$ height) and for flexural strength, prism (150 $\mathrm{mm}$ depth, width and $600 \mathrm{~mm}$ length). The Mehran University Research Journal of Engineering and Technology, Vol. 39, No. 2, April 2020 [p-ISSN: 0254-7821, e-ISSN: 2413-7219] 
variables for both types of specimens i.e. cylinders and prisms include mix ratios $(1: 2: 4$ and $1: 1.5: 3)$ and amount of HSH's (0, 1, 2 and 3\%). While, W/C ratio $(\mathrm{W} / \mathrm{C}=0.50)$ kept constant for both mix designs. Total, twenty-four (24) concrete prisms and twentyfour concrete cylinders, twelve at each mix ratio were cast. Batching, mixing and casting of specimens were performed according to standard code ASTM C92a. The UTM is used for testing of specimens in flexural strength at central point loading conditions and tensile strength by splitting cylinder method.

At each percentage of $\mathrm{HSH}$, three specimens were cast and tested. Average of three specimens at a specified percentage of $\mathrm{HSH}$ is taken as a result. Finally, the comparison is made as specimens without and with different proportions of HSH.

\subsection{Materials}

Ordinary Portland cement with local market brand name "Lucky Cement" was used. All preliminary tests of cement were carried out in the laboratory by following the standard procedure of ASTM C30 and results are enumerated in Table 1 . Hill sand with the brand name "Bolahari Hill Sand" and crushed coarse aggregates with the brand name "Petaro Crushed Coarse Aggregates" locally available were used. Aggregates were washed with drinking water for removing the dust before conducting the preliminary tests and using them in making of concrete. All preliminary required tests of aggregate were carried out under the umbrella of ASTM C33 and summary of results is listed in Table 1.

$\mathrm{HSH}$, used in this study are irrespective of size, it may vary from few $5 \mathrm{~mm}$ to $100 \mathrm{~mm}$. HSH was collected from salon shops of the local market in polyethene bags. Segregation of hairs was done by removing the unwanted materials like tissue papers. HSH washed twice with washing powder for removing the dust and then kept spared for drying. The dry HSH were batched by weight and beaten with a small wooden stick for breaking of hair lumps. Hair lumps generated, when washed with water and those lumps were not able to mix thoroughly in concrete. So, hair lumps were slowly beaten with a wooden stick for separating hair from lumps. Thus, segregated hairs were mixed in a concrete mixer in wet mix slowly and gradually, after mixing of other concrete ingredients as shown in Fig. 1 , for uniform mixing.

\begin{tabular}{|c|c|c|}
\hline \multicolumn{3}{|c|}{$\begin{array}{c}\text { TABLE 1: SUMMARY OF MATERIAL } \\
\text { PROPERTIES }\end{array}$} \\
\hline No & $\begin{array}{c}\text { Name of } \\
\text { Test/Property/Material }\end{array}$ & Results \\
\hline \multicolumn{3}{|c|}{ Cement (OPC) } \\
\hline 1. & Normal Consistency & 0.33 \\
\hline 2. & $\begin{array}{l}\text { Initial Setting Time } \\
\text { (minutes) }\end{array}$ & 50 \\
\hline 3. & $\begin{array}{l}\text { Final Setting Time } \\
\qquad \text { (minutes) }\end{array}$ & 150 \\
\hline \multicolumn{3}{|c|}{ Coarse Aggregates } \\
\hline 1. & Size, $\mathrm{mm}$ & 20 \\
\hline 2. & $\begin{array}{l}\text { Apparent Specific } \\
\text { Gravity }\end{array}$ & 2.63 \\
\hline 3. & $\begin{array}{l}\text { Absolute Specific } \\
\text { Gravity }\end{array}$ & 2.62 \\
\hline 4. & Water Absorption (\%) & 0.80 \\
\hline 5. & Density $\left(\mathrm{kN} / \mathrm{m}^{3}\right)$ & 14.7 \\
\hline \multicolumn{3}{|c|}{ Fine Aggregates } \\
\hline 1. & Fines Modulus & 2.4 \\
\hline 2. & $\begin{array}{l}\text { Apparent Specific } \\
\text { Gravity }\end{array}$ & 2.61 \\
\hline 3. & $\begin{array}{l}\text { Absolute Specific } \\
\text { Gravity }\end{array}$ & 2.60 \\
\hline 4. & Water Absorption (\%) & 1.5 \\
\hline 5. & Density, $\left(\mathrm{kN} / \mathrm{m}^{3}\right)$ & 19.1 \\
\hline
\end{tabular}

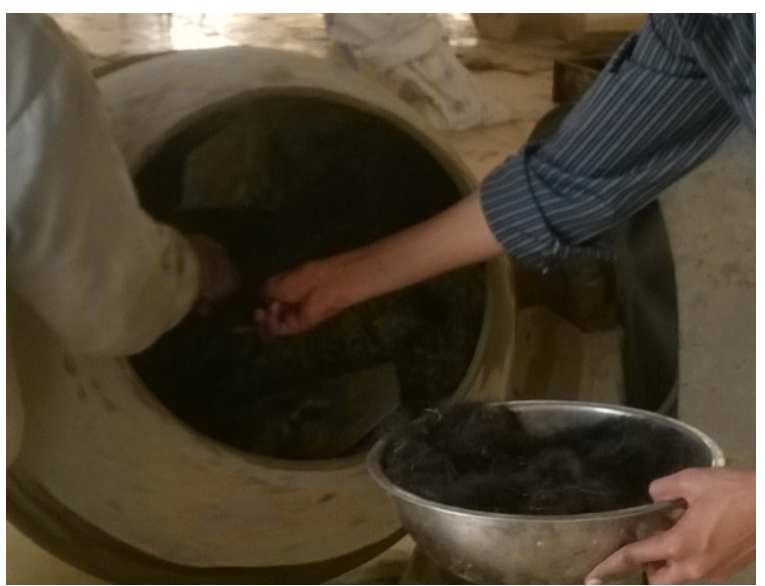

FIG. 1. AN OVERVIEW OF MIXING OF HSH IN CONCRETE MIXER [29] 


\section{EXPERIMENTAL RESULTS AND DISCUSSION}

\subsection{Workability of Concrete}

Workability of fresh concrete in terms of the slump was examined. This test is carried under the compliance of ASTM C143-90a. Fresh concrete prepared in the laboratory at room temperature was placed in a pan and then filled into slump cone for determining the workability of fresh concrete. Three tests were carried out at each proportion of HSH and average of all taken as a result. These experimental results are given in Tables 2-3. While Fig. 2 depicts the graphical representation of the variation in the slump values with an increasing percentage of $\mathrm{HSH}$. Slump values are recorded higher at 1:1.5:3 mix ratio; $140 \mathrm{~mm}$ and $46 \mathrm{~mm}$ than 1:2:4 mix ratio; 51 and $5 \mathrm{~mm}$ at 0 and $3 \%$ of $\mathrm{HSH}$ respectively. This reduction may be due to lower aggregates to cement ratio and smaller specific area of aggregates to be covered with cement paste in the former mix. Furthermore, with an increasing percentage of $\mathrm{HSH}$, slump decreases gradually in both mixes, higher at concrete without and lower at concrete with 3\% of HSH. This trend might be due to an increased specific area of materials i.e. more $\mathrm{HSH}$ in concrete required more cement paste to cover its area, which results in less amount of water remained for workability. Overall, workability decreases with increasing amount of HSH fibers.

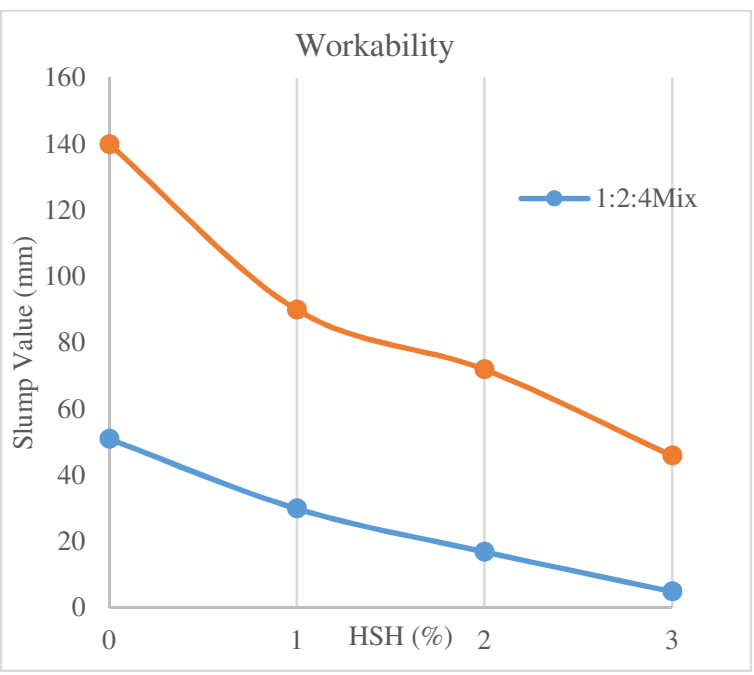

FIG. 2. WORKABILITY OF HSH FIBER CONCRETE

\subsection{Splitting Tensile Strength of Concrete}

The splitting tensile strength of concrete is investigated at 28 days curing period. Tensile strength is determined by following the ASTM C 496-90. The standard cylindrical specimens were placed in the jaws of UTM horizontally and the load is applied till it split into two parts. Three specimens at each proportion of HSH were tested and then the average of three is taken as a result as given in Tables 2-3. While, Fig. 3, shows a graphical representation of the variation in tensile strength. The strength increases gradually with an increasing percentage of HSH in both mixes as compared to plain concrete, till it achieved maximum value of 2.24 and $2.25 \mathrm{MPa}$ at $1 \%$ of $\mathrm{HSH}$ fiber in 1:2:4 and 1:1.5:3 mix ratios respectively. And then it decreases throughout at other proportions of HSH. The maximum advantage of HSH fibers is in leaner than richer mix due to $15 \%$ higher strength at $1 \%$ of $\mathrm{HSH}$ fiber than controlled mix while less advantage in later mix i.e. $4.2 \%$ increment in strength. This increment in strength is might be due to the strength of fiber, adequate physical or chemical bonding of fibers with the matrix. Fibers could have arrested the propagation of microcracks to occur which eventually increased the tensile capacity of the concrete. As the increment was expected to be higher at a higher percentage of HSH fibers but the inverse trend is observed in both mixes. The lower splitting tensile strength might be due to the lower density of concrete at higher content of fibers and this can be observed in Fig. 5; lower density at a higher amount of fibers.

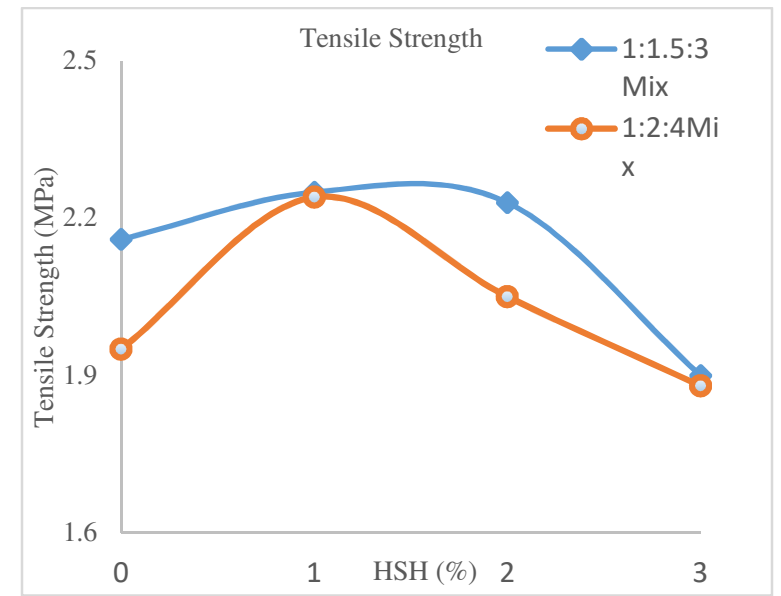

FIG. 3: SPLITTING TENSILE STRENGTH OF HSH FIBER CONCRETE

Mehran University Research Journal of Engineering and Technology, Vol. 39, No. 2, April 2020 [p-ISSN: 0254-7821, e-ISSN: 2413-7219] 
Human Scalp Hair as Fiber Reinforcement in Cement Concrete

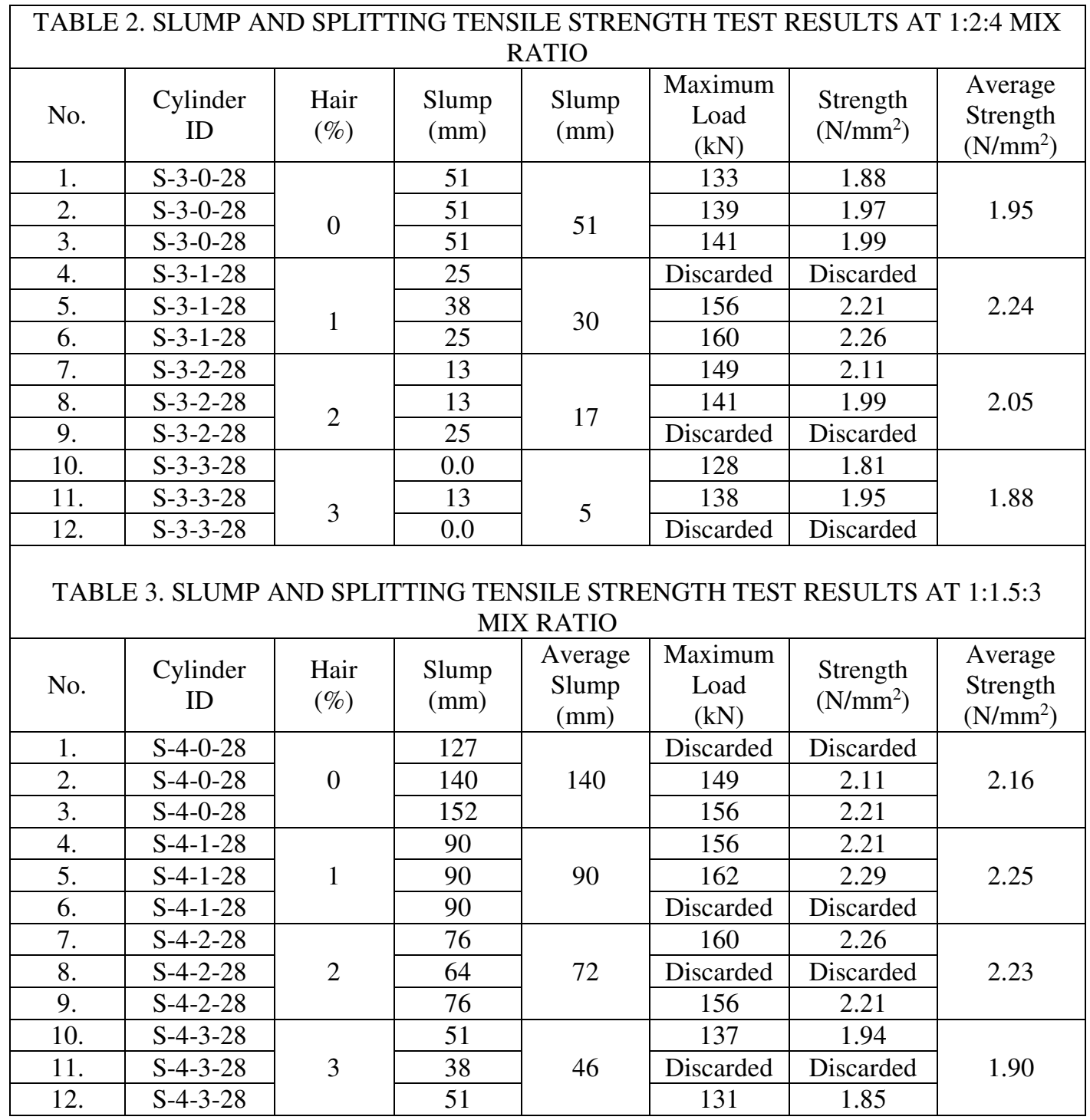

\subsection{Flexural Strength of Concrete}

Similarly, the flexural strength of concrete is also determined at 28 days curing period. This test is performed according to ASTM C293/293M, central point load method. The concrete beam/prism was placed in the simply supported assembly as shown in Fig. 4, and the load is applied through UTM until it breaks into two parts. Three specimens at each proportion of $\mathrm{HSH}$ were tested and the average of three is reported as final result, as given in Tables 4-5. Fig. 5 represents the trend of flexural strength at different proportions of HSH fibers. Fluctuation in trend is observed here; strength decreases at 1 and 3\% of HSH but increases at $2 \%$ of HSH. The enhancement is about $7.4 \%$ and $6 \%$ at $1: 2: 4$ and $1: 1.5: 3$ mix ratios respectively. This tendency is completely different as compared to splitting tensile strength of concrete; might be due to variation in length of fibers. The effective length at $2 \%$ of HSH might be sufficient to hold the crack which resulted in an increase in flexural strength. The other factors could be higher bond strength between fiber and concrete, more fibers oriented perpendicularly to the cracks generated during loading. If this is the reason, the strength would have been higher at a higher proportion of fibers but it decreases at $3 \%$ of $\mathrm{HSH}$. 

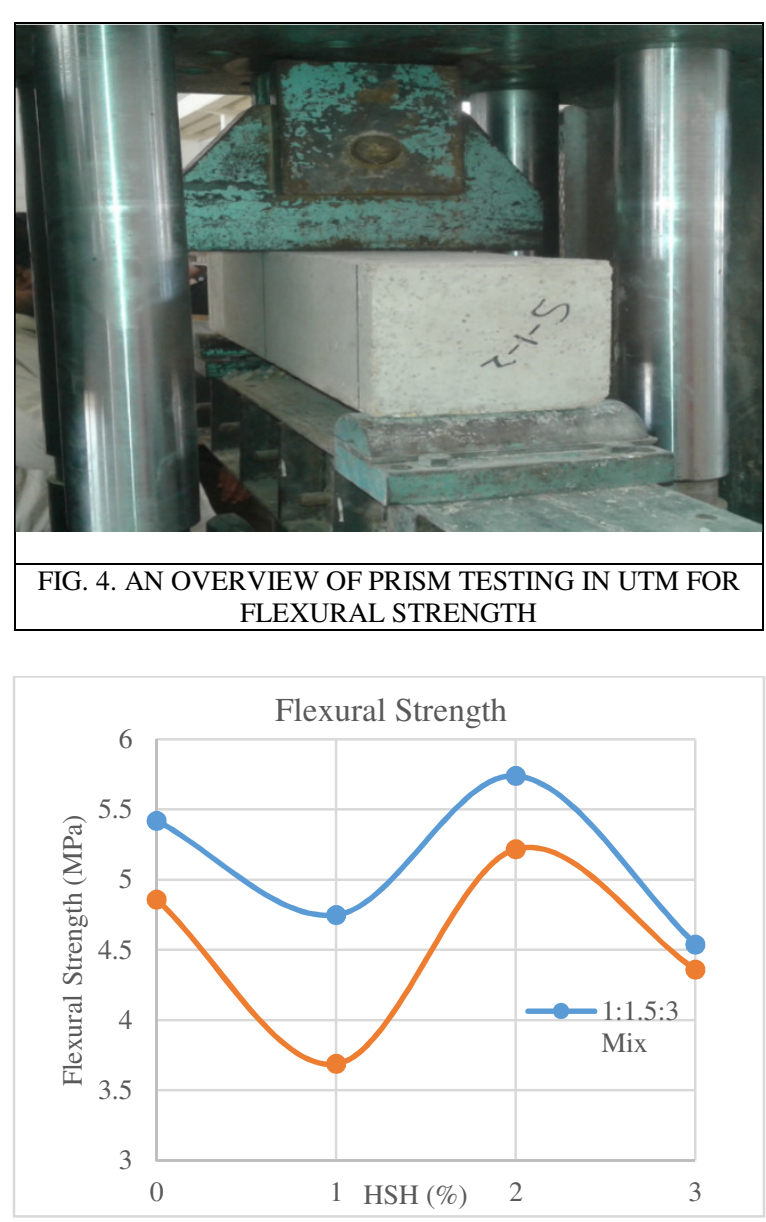

FIG. 5. FLEXURAL STRENGTH OF HSH FIBER CONCRETE

This less strength can be due to the high variation of the length of fiber; it is possible that the length of fibers at $3 \%$ of fiber is less than other proportions of fibers. As from visual observation during the mixing of concrete, at $3 \%$ of $\mathrm{HSH}$, fibers became a ball and it was difficult to separate them. Thus, balling of fibers put an adverse effect on any type of strength. This was the main reason at a higher proportion of $\mathrm{HSH}$, fibers got interlocked which resulted in an amalgamation in concrete and these fiber balls are like a hole in concrete which reduces splitting as well as flexural strength of concrete.

\subsection{Density of Concrete}

The density of concrete is measured at each percentage of HSH to know the correlation of strength and density of concrete. Density was determined by weighing the concrete cylinders in electronic weight balance in SSD (Surface Saturated Drying) conditions. After curing,

\begin{tabular}{|c|c|c|c|c|c|}
\hline \multicolumn{6}{|c|}{$\begin{array}{l}\text { TABLE 4. FLEXURAL STRENGTH TEST RESULTS AT } \\
\text { 1:2:4 MIX RATIO }\end{array}$} \\
\hline $\mathrm{N}$. & $\begin{array}{l}\text { Cylinder } \\
\text { ID }\end{array}$ & $\begin{array}{l}\text { Hair } \\
(\%)\end{array}$ & $\begin{array}{l}\text { Max. } \\
\text { Load } \\
(\mathrm{kN})\end{array}$ & $\begin{array}{l}\text { Strength } \\
\left(\mathrm{N} / \mathrm{mm}^{2}\right)\end{array}$ & $\begin{array}{l}\text { Average } \\
\text { Strength } \\
\left(\mathrm{N} / \mathrm{mm}^{2}\right)\end{array}$ \\
\hline 1. & S-2-0-28 & \multirow{3}{*}{0} & 15 & 3.85 & \multirow{3}{*}{4.86} \\
\hline 2. & S-2-0-28 & & 18 & 4.62 & \\
\hline 3. & S-2-0-28 & & 24 & 6.10 & \\
\hline 4. & S-2-1-28 & \multirow{3}{*}{1} & 16 & 4.16 & \multirow{3}{*}{3.69} \\
\hline 5. & S-2-1-28 & & 13 & 3.33 & \\
\hline 6. & S-2-1-28 & & 14 & 3.57 & \\
\hline 7. & S-2-2-28 & \multirow{3}{*}{2} & 20 & 5.19 & \multirow{3}{*}{5.22} \\
\hline 8. & S-2-2-28 & & 19 & 4.81 & \\
\hline 9. & S-2-2-28 & & 22 & 5.66 & \\
\hline 10. & S-2-3-28 & \multirow{3}{*}{3} & 15 & 3.85 & \multirow{3}{*}{4.36} \\
\hline 11. & S-2-3-28 & & 20 & 5.13 & \\
\hline 12. & S-2-3-28 & & 16 & 4.11 & \\
\hline
\end{tabular}

\begin{tabular}{|c|c|c|c|c|c|}
\hline \multicolumn{6}{|c|}{$\begin{array}{l}\text { TABLE 5. FLEXURAL STRENGTH TEST RESULTS AT } \\
\text { 1:1.5:3 MIX RATIO }\end{array}$} \\
\hline No. & $\begin{array}{l}\text { Cylinder } \\
\text { ID }\end{array}$ & $\begin{array}{c}\text { Hair } \\
(\%)\end{array}$ & $\begin{array}{l}\text { Max. } \\
\text { Load } \\
(\mathrm{kN})\end{array}$ & $\begin{array}{l}\text { Strength } \\
\left(\mathrm{N} / \mathrm{mm}^{2}\right)\end{array}$ & $\begin{array}{l}\text { Average } \\
\text { Strength } \\
\left(\mathrm{N} / \mathrm{mm}^{2}\right)\end{array}$ \\
\hline 1. & S-1-0-28 & \multirow{3}{*}{0} & 18 & 4.53 & \multirow{3}{*}{5.42} \\
\hline 2. & S-1-0-28 & & 22 & 5.66 & \\
\hline 3. & S-1-0-28 & & 23 & 6.05 & \\
\hline 4. & S-1-1-28 & \multirow{3}{*}{1} & 21 & 5.31 & \multirow{3}{*}{4.75} \\
\hline 5. & S-1-1-28 & & 16 & 4.04 & \\
\hline 6. & S-1-1-28 & & 19 & 4.90 & \\
\hline 7. & S-1-2-28 & \multirow{3}{*}{2} & 26 & 6.61 & \multirow{3}{*}{5.74} \\
\hline 8. & S-1-2-28 & & 19 & 4.84 & \\
\hline 9. & S-1-2-28 & & 22 & 5.78 & \\
\hline 10. & S-1-3-28 & \multirow{3}{*}{3} & 17 & 4.46 & \multirow{3}{*}{4.54} \\
\hline 11. & S-1-3-28 & & 16 & 4.07 & \\
\hline 12. & S-1-3-28 & & 20 & 5.08 & \\
\hline
\end{tabular}

cylinders were kept one day in the shade for SSD conditions and then the weight is determined which is given in Table 6 and Fig. 6 . The graph represents, with an increasing percentage of the amount of hairs, the density of concrete decreases. The maximum density is recorded at $0 \%$ of $\mathrm{HSH}$, while minimum at $3 \%$ of HSH in both types of mix ratios. Overall, reduction in density at 1:2:4 and 1:1.5:3 mix ratios is $2.0 \%$ and $8.0 \%$ respectively. This reduction in density indicates that the density of hairs is lower than that of ingredients of concrete and hairs entrapped more air as compared to normal concrete. Even, both reason can be possible for reduction in density and strength of concrete.

The reduction in tensile and flexural strength can be justified based on the reduction of the density of concrete with increasing the amount of fibers in concrete. But, it is only one specified proportion of HSH where both strengths sored to a certain value as 


\begin{tabular}{|c|c|c|c|c|c|c|c|}
\hline \multicolumn{8}{|c|}{ TABLE 6. DENSITY OF HARDENED CONCRETE } \\
\hline \multirow[b]{2}{*}{ No. } & \multirow[b]{2}{*}{$\begin{array}{l}\text { Hair } \\
(\%)\end{array}$} & \multicolumn{3}{|c|}{ At 1:2:4 Mix Ratio } & \multicolumn{3}{|c|}{ At 1:1.5:3 Mix Ratio } \\
\hline & & Weight (Kg) & Density $\left(\mathrm{Kg} / \mathrm{m}^{3}\right)$ & $\begin{array}{c}\text { Average Density } \\
\left(\mathrm{Kg} / \mathrm{m}^{3}\right)\end{array}$ & $\begin{array}{c}\text { Weight } \\
(\mathrm{Kg})\end{array}$ & Density $\left(\mathrm{Kg} / \mathrm{m}^{3}\right)$ & $\begin{array}{c}\text { Average Density } \\
\left(\mathrm{Kg} / \mathrm{m}^{3}\right)\end{array}$ \\
\hline 1. & \multirow{3}{*}{0} & 12.7 & 2283.8 & \multirow{3}{*}{2292.8} & 12.85 & 2310.70 & \multirow{3}{*}{2310.73} \\
\hline 2. & & 12.8 & 2301.7 & & 12.90 & 2319.73 & \\
\hline 3. & & 12.75 & 2292.8 & & 12.80 & 2301.70 & \\
\hline 4. & \multirow{3}{*}{1} & 12.8 & 2301.7 & \multirow{3}{*}{2289.8} & 12.25 & 2202.84 & \multirow{3}{*}{2193.85} \\
\hline 5. & & 12.5 & 2247.8 & & 12.20 & 2193.85 & \\
\hline 6. & & 12.9 & 2319.7 & & 12.15 & 2184.86 & \\
\hline 7. & \multirow{3}{*}{2} & 12.7 & 2283.8 & \multirow{3}{*}{2268.8} & 12.00 & 2157.89 & \multirow{3}{*}{2172.83} \\
\hline 8. & & 12.6 & 2265.8 & & 12.10 & 2175.87 & \\
\hline 9. & & 12.55 & 2256.8 & & 12.15 & 2184.86 & \\
\hline 10. & \multirow{3}{*}{3} & 12.55 & 2256.8 & \multirow{3}{*}{2256.8} & 11.75 & 2112.93 & \multirow{3}{*}{2124.92} \\
\hline 11. & & 12.6 & 2265.8 & & 11.90 & 2139.90 & \\
\hline 12. & & 12.5 & 2247.8 & & 11.80 & 2121.92 & \\
\hline
\end{tabular}

discussed earlier. This could be possible at that specified percentage of HSH might have strong bonding and pull-out strength due to sufficient length that could have arrested the cracks to develop and ultimately resulted in an increase in strength. Although $\mathrm{HSH}$ is organic waste, it requires considerable time for complete disintegration when dumped underneath soil or left openly. But the trend of disintegration rate in cement is yet to be investigated, which is not in the scope of this research. Thus, it is possible that hair fiber might have damaged quickly when mixed with cement due to the alkaline nature of concrete. This possibility was investigated over failure surface of tested cylinders and beams with naked eyes, and it was observed that few hairs were visible on the failure surface as compared to fresh concrete in which more hairs were clearly visible. So, it requires further detail experimental investigation on the effect of disintegration rate on different properties of concrete.

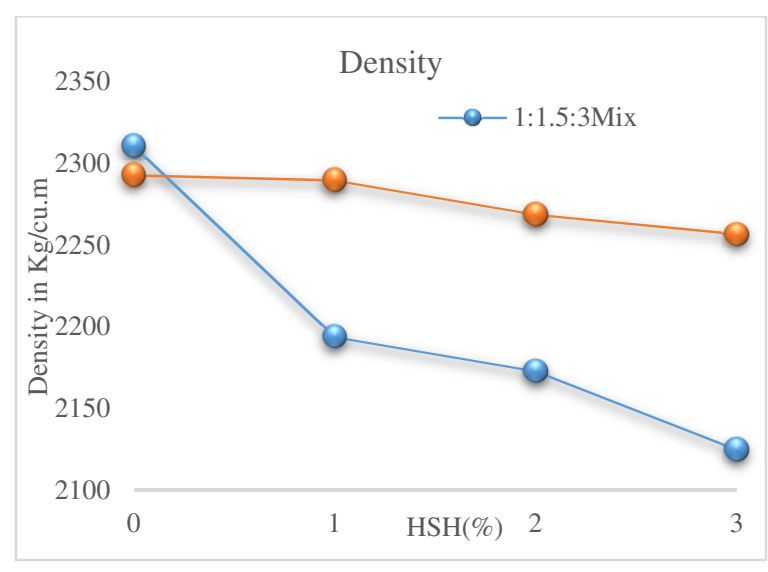

FIG. 6. DENSITY OF HSH FIBER CONCRETE

\section{FURTHER RESEARCH}

$\mathrm{HSH}$ as fiber in concrete is an emerging field for research. So, it is highly desirable to check the various properties of hair, fresh and harden concrete. Different properties of concrete can be investigated like workability, elasticity, ductility, long term durability etc. But all these properties can only be investigated properly when characteristics properties of hair are known. Therefore, it is important to understand the basic properties of hair, especially long term sustainability of hair fiber concrete is necessary because of the organic nature of hair. In addition, other natural, recycled or industrial manufactured fibers can be added in concrete to investigate the advantage of HSH fiber over other fibers. Hence, this study just starts of work on hair as fiber in concrete but an extensive study is still required to understand the behaviour of hair fibers and to generate certain design guidelines for achieving proper benefit and wide acceptability in the construction industry.

\section{CONCLUSION}

This research was conducted to know the behaviour of concrete in terms of its physical properties, specifically mechanical properties when HSH as fibers are added. Based on the results of this experimental investigation on $\mathrm{HSH}$ as fiber in concrete, the following conclusions are drawn:

The splitting tensile strength increases to $15 \%$ and $4.2 \%$ in $1: 2: 4$ and $1: 1.5: 3$ mix ratio at $1 \%$ addition of $\mathrm{HSH}$ respectively. And it decreases at other percentages of hair fibers.

Mehran University Research Journal of Engineering and Technology, Vol. 39, No. 2, April 2020 [p-ISSN: 0254-7821, e-ISSN: 2413-7219] 
(ii) The flexural strength of HSH fiber concrete increases to $7.4 \%$ and $6 \%$ in $1: 2: 4$ and $1: 1.5: 3$ mix ratio respectively at $2 \%$ addition of hair fibers. It decreases at other percentages of HSH fibers.

(iii) Comparatively, higher value in both strengths was recorded at 1:2:4 mix ratio rather 1:1.5:3 mix ratio at the same watercement ratio.

(iv) Workability in terms of slump value decreases with an increasing percentage of $\mathrm{HSH}$; lower value is recorded at $3 \%$ of $\mathrm{HSH}$. Comparatively, higher values of a slump are observed at 1:1.5:3 mix ratio.

(v) The density of concrete decreases as the amount of $\mathrm{HSH}$ fibers increases. Reduction in density is $2.0 \%$ and $8.0 \%$ at $1: 2: 4$ and 1:1.5:3 mix ratios respectively.

\section{ACKNOWLEDGMENT}

Authors are thankful to the Directorate of PostGraduate Studies and the Department of Civil Engineering, Mehran University of Engineering \& Technology, Jamshoro, Pakistan for financial support to accomplish this research of $\mathrm{ME}$ thesis of the corresponding author.

\section{REFERENCES}

[1] Gupta, A., "Human Hair (Waste) and Its Utilization: Gaps and Possibilities”, Journal of Waste Management, Volume2014, Article ID 498018, pp. 1-17, 2014.

[2] Brebu, M., and Spiridon, I., "Thermal Degradation of Keratin Waste", Journal of Analytical and Applied Pyrolysis, Volume 91, No. 2, pp. 288-295, 2011.

[3] Neville A. M., and Brooks J. J., "Properties of Concrete", $2^{\text {nd }}$ Edition, pp. 269, Pearson Education Ltd. England, 2007.

[4] United Nations-Department of Economic and Social Affairs (Population Division), "World Population 2012", United Nations Publication, USA, August, 2013.

[5] Gupta C. S., "Clay Traditional Material for Making Handicrafts", Indian Journal of
Traditional Knowledge, Volume 7, No. 1, pp. 166-124, 2008.

[6] Bantia, N., and Gupta, R., "Influence of Polypropylene Fiber Geometry on Plastic Shrinkage Cracking in Concrete", Cement and Concrete Research Journal, Volume 36, No. 7, pp. 1263-12679, 2006.

[7] Dvorkin, L., Dvorkin, O., Zhitkovsky, V., and Ribakov, Y., "A Method for Optimal Design of Steel Fiber Reinforced Concrete Composition", Material and Design Journal, Volume 32, No. 1, pp. 246-254, 2011.

[8] Dvorkin, L., Dvorkin, O., and Nwaubani, S., "Construction Materials", Nova Science Publishers Inc., pp. 409,New York,2010.

[9] Day, K. W., "Concrete Mix Design, Quality Control and Specification", $3^{\text {rd }}$ Edition, Taylor and Francis Publisher, pp. 214, New York, 2006.

[10] Bayramov, F., Tasdemir, C., Tasdemir, M. A., "Optimization of Steel Fiber Reinforced Concrete by Means of Statistical Response Surface Method", Cement and Concrete Composites, Volume 26, No. 6, pp. 665-675, 2004.

[11] Banthia, N., and Soleimani, S.M., "Flexural Response of Hybrid Fiber Reinforced Cementitious Composites", ACI Materials Journal, Volume 102, No. 5, pp. 382-389, 2005.

[12] Li, V.C., Wang, S., and Wu, C., "Tensile Strain-Hardening Behavior of Polyvinyl Alcohol Engineered Cementitious Composites (PVA-ECC)", ACI Material Journal, Volume 98, No. 6, pp. 483-492, 2001.

[13] Nelson, P.K., Li, V.C., and Kamada, T., "Fracture Toughness of Microfiber Reinforced Cement Composites", ACI Material Journal, Volume 14, No. 5, pp. 384391, 2002.

[14] Balendran, R.V., Zhou, F.P., and Nadeem, A., "Influence of Steel Fibers on Strength and Ductility of Normal and Light Weight High Strength Concrete”, Building and Environment Journal, Volume 37, No. 12, pp. 1361-1367, 2002. 
[15] Balaguru, P., and Najm, H., "HighPerformance Fiber Reinforced Concrete Mixture Properties with High Fiber Volume Fractions", ACI Materials Journal, Volume 101, pp. 281-286, 2004.

[16] Banthia, N., Zanoti, C., and Sappakittipakron, M., "Sustainable Fiber Reinforced Concrete for Repair Applications", Construction and Buildings Materials, Volume 67, Part-C, pp. 405-412, 2014.

[17] Bantia, N., and Gupta, R., "Influence of Polypropylene Fiber Geometry on Plastic Shrinkage Cracking in Concrete", Cement and Concrete Research Journal, Volume 36, No. 7, pp. 1263-12679, 2006.

[18] Victor, C., and Li., "On Engineered Cementitious Composites: A Review of the Material and Its Applications", Journal of Advanced Concrete Technology, Volume 1, No. 3, pp. 215-230, 2003.

[19] Tapfers, R., "Report on Investigation of Different Types of Fibers to Strengthen Cement Paste, Mortar and Concrete", Department of Civil \& Environment Engineering, Structural Engineering, Concrete Structures, Chalmers University of Technology, Sweden.

[20] Dugenci, O., Haktanir, T., and Altun, F., "Experimental Research for the Effect of High Temperature on the Mechanical Properties of Steel Fiber Reinforced Concrete", Construction and Building Materials, Volume 75, pp. 82-88, 2015.

[21] Wang, H., and Belorbi, A., "Ductility Characteristics of Fiber Reinforced Concrete Beams Reinforced with FRP Rebar", Construction and Building Materials, Volume 25, No. 5, pp. 2391-2401, 2011.

[22] Parameswaran, V. S., "Fiber Reinforced Concrete: A Versatile Construction Material", Building and Environment Journal, Volume 26, No. 3, pp. 301-305, 1991.

[23] Rossi, P., "Ultra-High-Performance Fiber Reinforced Concretes", Concrete International, No. 12, pp. 46-52, 2001.
[24] Heymans, N.M., "Archaeology, Experimental Archaeology and Ethno Archaeology on Bread Ovens in Syria", Civilization, Volume 49, pp 197-122, 2002.

[25] Al-Darbi, M.M., Saeed, N.O., Ajijolavia, L.O., and Aslam, M.R., "A Novel Well Cementing Technology Using Natural Fibers", Petroleum Science and Technology, Volume 24, No. 11, pp. 1267-1282, 2006.

[26] Jain, D., and Kothari, A., "Hair Fiber Reinforced Concrete", Research Journal of Recent Science, Volume 1, pp.128-133, 2012.

[27] Akthar, J.N., and Ahmed, S., "The Effect of Randomly Oriented Hair Fiber on Mechanical Properties of Fly Ash Based Hollow Block for Low Height Masonry Structures", Asian Journal of Civil Engineering, Volume 10, No.2, pp.221-228, 2009.

[28] Balaguru, P.N., and Surendra, P.S., "Fiber

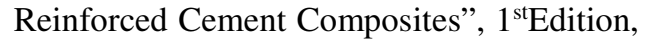
McGraw Hill Publisher, USA, 1996.

[29] Meghwar, S.L., Kheskheli, G.B., Kumar, A., and Mahar, R.B., "Recycling of Human Scalp Hair as Environmental Friendly Material in Cement Concrete"; Proceedings of $4^{\text {th }}$ International Conference on Energy, Environment and Sustainable Development, Energy and Environment Engineering Research Group, Paper ID: EESD_2016_54, Mehran University of Engineering \& Technology, Jamshoro, Pakistan, November 1-3, 2016.

[30] Batebi, Y., Mirzagoltarbar, A., Shabanian, S.M., and Fateri, S., "Experimental Investigation of Shrinkage Nano Hair Reinforced Concrete", Iranica Journal of Energy and Environment, Volume 4, No.1, pp. 68-72, 2013.

[31] Chung, D.D.L., "Dispersion of Short Fibers in Cement", Journal of Material in Civil Engineering, Volume 17, No. 4, pp. 379-383, 2005.

[32] Stahli, P., Custer, R., and Van Mier, J., “On Flow Properties, Fiber Distribution, Fiber Orientation and Flexural Behavior of FRC",

Mehran University Research Journal of Engineering and Technology, Vol. 39, No. 2, April 2020 [p-ISSN: 0254-7821, e-ISSN: 2413-7219] 
Materials and Structures Journal, Volume 41, No. 1, pp. 189-196, 2008.

[33] Gettu, R., Gardner, D.R., Saldivar, H., and Barragan, B.E., "Study of the Distribution and Orientation of Fiber in SFRC Specimens", Materials and Structures, Volume 38, pp. 31-37, 2005.

[34] Maddah, M.S., and Bencheikh, V., "Properties of Concrete Reinforced with Different Kinds of Industrial Waste Fiber Materials", Construction and Building Materials, Volume 23, pp. 3196-3205, 2009.
[35] Boolekbache, B., Hamrat, M., Chemrook, M., and Amziane, S., "Flowability of Fiber Reinforced Concrete and Its Effects on the Mechanical Properties of the Material", Construction and Building Materials Journal, Volume 24, No. 9, pp. 1664-1671, 2010. 